\title{
EVOLVENS CSIGA GYÁRTÁSI PONTOSSÁGÁNAK VIZSGÁLATA KINEMATIKAI MODELL SEGÍTSÉGÉVEL
} AN ANALYSIS OF MANUFACTURING PRECISION OF
INVOLUTE WORMS USING A KINEMATICAL MODEL

Kelemen Csongor, ${ }^{1}$ Máté Márton ${ }^{2}$

${ }^{1}$ Sapientia Erdélyi Magyar Tudományegyetem, Marosvásárhelyi Kar, Marosvásárhely, Románia, kelemen.e.csongor@stuent.ms.sapientia.ro

${ }^{2}$ Sapientia Erdélyi Magyar Tudományegyetem, Marosvásárhelyi Kar, Gépészmérnöki Tanszék, Marosvásárhely, Románia, mmate@ms.sapientia.ro

\begin{abstract}
The manufacturing precision of involute worms constitutes a major requirement. On the one hand, the worm constitutes the input element of the worm drive; secondly, the involute helical surface is the basic surface of an involute worm-hob. This paper presents an analytic comparison between the involute surfaces obtained using theoretical equations, kinematic simulation of the cutting and the surface charged with errors. The surface error is considered the distance along the normal direction to the theoretical surface, measured between this and the surface charged with simulated manufac-turing errors. The main sources of errors are considered the center-error of the edge plane, the edge profile error and deviation of the axial feed direction from the axis of the worm. The theoretical re-sults allow us to conclude that the influence of the edge profile error is the largest. It is followed by the parallelism error between the feed direction and the axis of the worm, and finally, the center error of the tool edge.
\end{abstract}

Keywords: involute worm, profile error, positioning error.

\section{Összefoglalás}

Az evolvens csigák gyártáspontossága igen fontos követelmény, részben azért, mert a működő csigahajtás egyik elemét képezik, másrészt pedig azért, mert az evolvens fogazat lefejtő csigamarójának alapfelületét képezik. Jelen tanulmány összehasonlító vizsgálatot valósít meg az elméleti evolvens csavarfelület, a késsel gyártott elméleti, hibamente és a valós csavarfelületek között. A hibát az elméleti evolvens csavarfelület és a szimulált valós körülmények között létrejövő csavarfelület közötti, normálirányú különbségként értelmezzük. A hibát a lefejtő él magassághibája, a lefejtő él profilszöghibája, illetve a szerszámgép tengelypárhuzamosság-hibájának függvényében vizsgáltuk. Az elméleti vizsgálat eredményeként kijelenthetjük, hogy a legnagyobb hibát a kés profilhibája okozza. Ezután következik a párhuzamosságeltérés okozta hiba, és legvégül az él magassághibája.

Kulcsszavak: evolvens csiga, profilhiba, beállítási hiba.

\section{Az evolvens csiga szerepe}

A gépgyártás - legyen az bármennyire korszerű és pontos infrastruktúrára illesztve - többszörösen összetett fizikai és kémiai jelenségek sorozatát jelenti, amelyek paraméterei sztochasztikusan változnak, és ezáltal az elméleti beállítási ponttól eltolják a rendszer kimenetét [1]. Innen származnak a gyártási hibák is, amelyeknek adott korláton belül való tartása kizárólag a gyártási folyamatok alapos ismeretében lehetséges.

Lényeges itt kiemelni a gyártási folyamatok modellezésének fontosságát, a lehetséges hibák meg- 
jelenésének előrelátásával, ezeknek minőségi és mennyiségi kielemzésével, amelyek alapján adott folyamat sikeres lefuttatását vagy akadályoztatását előre kimondhatjuk.

A gépgyártás területén, az alkatrészgyártás sajátos tartományában az egyik lényeges kihívás a geometriai pontosság betartása. Minél nagyobbak az adott gépelemmel szemben támasztott követelmények, annál nagyobb fontossággal bír a lehetséges gyártási hibák előre látása, azok kiküszöbölése céljából.

A csigahajtások gyártása, mint ismeretes, kivételesen pontos infrastruktúrát és folyamatirányítást igényel, hiszen a teherbírás, a kopás, a működés közbeni melegedés egyenes következménye a gyártott felület geometriájának, illetve ezeknek a bázis- vagy tájolófelületekhez való viszonyának [2, 3].

Az evolvens csiga vonalfelületű csiga, amelynek gyártása viszonylag egyszerű és költséghatékony. Bár a nagy teherbírású és nagy teljesítményü csigahajtások módosított profilú hajtások $[4,5]$, az evolvens csigahajtás átörököli az evolvens fogazatok előnyeit, ezért gépelemként is ajánlott az alkalmazása.

Az evolvens csavarfelület előállításának pontossága azért is fontos, mert a lefejtő csigamaró alapfelületét képezi. Ezzel intenzíven foglalkoztak az utóbbi két évtizedben is $[6,7,8]$.

Az evolvens csigát klasszikusan esztergálással állítják elő, egyenes élű késpár segítségével, ahol az élek meghatározó profilját tartalmazó síkok a csiga alaphengerét érintik. Ebből közvetlenül adódik két hibalehetőség: a kés profilsíkjának a csiga tengelyéhez való illesztéséből, illetve az él profilszögéből. Ez utóbbi szerszámgyártási hiba, illetve tájolási hiba összegzett hatásának eredménye. A harmadik, feltételezett hibaforrást a hoszszanti előtolás irányának a csiga tengelyétől való eltérésében gyanítjuk.

Bár a nagy teherbírású csigákat köszörülik, a napjainkban létező, gyakorlatilag kimeríthetetlen számú forgácsolólapka-minőségek lehetővé teszik az edzett alkatrészek definiált geometriájú szerszámokkal való megmunkálását, amivel a köszörülést ki lehet váltani. Simításról lévén szó, a forgácsolóegységet terhelő erők nem növekednek annyira, hogy a méretet az előírt pontossági osztályból kitolnák - annál inkább, hogy a jelenlegi szerszámgépek az edzett anyagok megmunkálására alkalmas merevséggel rendelkeznek.

Ezen feltételezések mellett időszerű a várható gyártási hibák analitikus modellezése.

\section{Az evolvens csavarfelület}

Az evolvens csavarfelületet parametrikus formában adjuk meg: először a matematikai generálás, majd pedig a késsel való lefejtés szerint.

\subsection{Elméleti evolvens csavarfelület}

Az elméleti evolvens csavarfelület generálása úgy történik, hogy a csavartengelyre merőleges $\left(y_{0} z_{0}\right)$ síkban definiált evolvens görbére $m_{a x} \pi$ emelkedésű csavarmozgást alkalmazunk, az $x_{0}$ tengely mentén. Az evolvensgörbe egyenleteit az 1. ábra alapján írjuk fel. A felírás különbözik a klasszikus, alapkörről való indításból következő összefüggésektől, mivel fölösleges a futóparaméter-értékeket a láb- és a fejkörsugár között beállítani, nem lévén szükség a nagyon kicsi, fémbe zárt alapkör és a lábkör közötti részre.

$\mathrm{Az}$ 1. ábra alapján az evolvens parametrikus egyenletei a következők:

$\left\{\begin{array}{c}y_{0}(\theta)=R_{b}\left(\sin \left(\theta-i n v \alpha_{0 t}\right)-\theta \cos \left(\theta-i n v \alpha_{0 t}\right)\right) \\ z_{0}(\theta)= \pm R_{b}\left(\cos \left(\theta-i n v \alpha_{0 t}\right)+\theta \sin \left(\theta-i n v \alpha_{0 t}\right)\right)\end{array}\right.$

A fej- és a lábkör között a $\theta$ futóparaméter értékeit az (1) kifejezésekből kifejezett polársugár lehatárolásának feltételéből kapjuk:

$R_{f} \leq R_{b} \sqrt{1+\theta^{2}} \leq R_{a} \Leftrightarrow \sqrt{\frac{R_{f}^{2}}{R_{b}^{2}}-1} \leq \theta \leq \sqrt{\frac{R_{a}^{2}}{R_{b}^{2}}-1}$

A 2. ábrán a csiga fogprofiljának homlokszelvényét szemléltetjük.

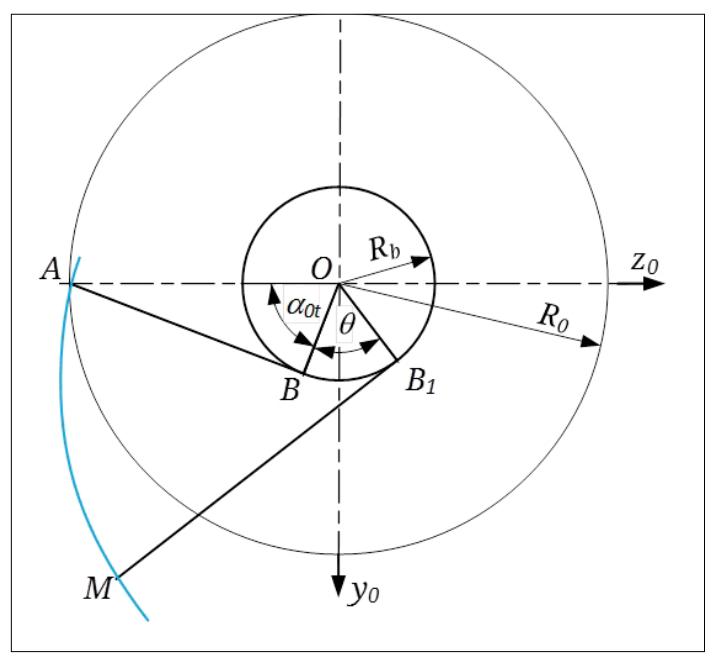

1. ábra. Az evolvens parametrikus alakjának definiálása csiga esetében 


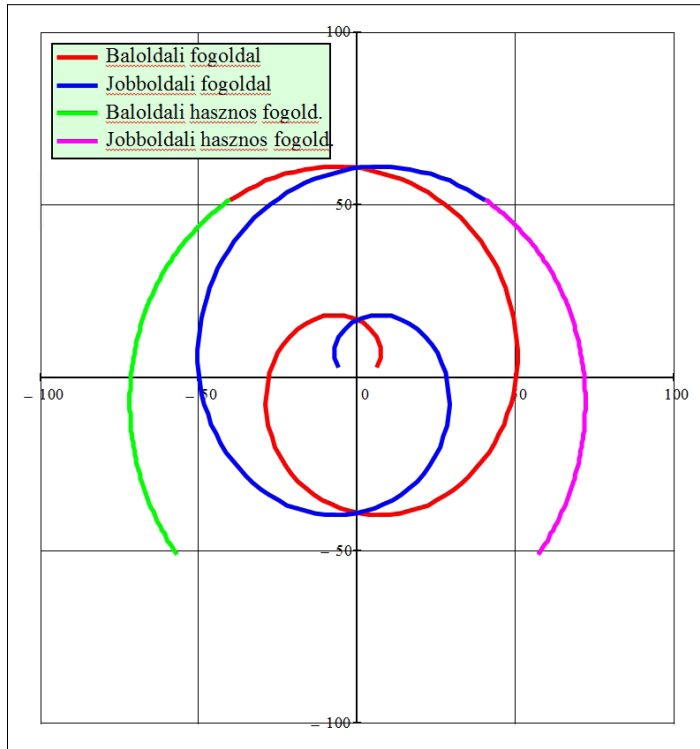

2. ábra. Evolvens csiga homlokszelvénye

Az evolvens csavarfelület az (1) alapszelvényre alkalmazott jobbsodrású csavarmozgással állítható elő, ahol a csavar paramétere

$$
p=\frac{i}{2} \frac{m_{n}}{\cos \lambda_{0}}
$$

Ezzel a csavarfelületek matematikai generálásból származó parametrikus egyenletei a következők lesznek:

$$
\left\{\begin{array}{c}
x_{0}(\theta, \varphi)=p \varphi \\
y_{0}(\theta, \varphi)=R_{b}(\sin E(\theta . \varphi)-\theta \cos E(\theta . \varphi)) \\
z_{0}(\theta, \varphi)= \pm R_{b}(\cos E(\theta . \varphi)+\theta \sin E(\theta . \varphi)) \\
E(\theta, \varphi)=\theta-\operatorname{inv} \alpha_{0 t}+\varphi
\end{array}\right.
$$

\subsection{Késsel lefejtett evolvens csavarfelület}

A késsel lejfejtett evolvens csavarfelület egyenleteit az alaphengert érintő párhuzamos síkokban illeszkedő élekre alkalmazott p paraméterü csavartranszformáció alkalmazásával kapjuk. A matematikai felület mint referenciafelület megőrzése céljából szükséges, hogy a késsel lefejtett evolvens csavarfelületek is tartalmazzák a koordináta-rendszer tengelyein illeszkedő osztóhengeri pontokat.

Az élek csavartengelyre húzott merőlegessel bezárt szögei, azaz a kés profilszögei [1, 7, 8]:

$$
\alpha_{s} \equiv \lambda_{b}=\operatorname{arctg} \frac{p}{R_{b}}
$$

Az élek $O x_{0}$ tengelytől való távolsága miatt a csavarhatás jelentkezik (3. ábra), ezért az egyenleteket a $\psi$ korrekciós szög figyelembevételével írjuk fel.

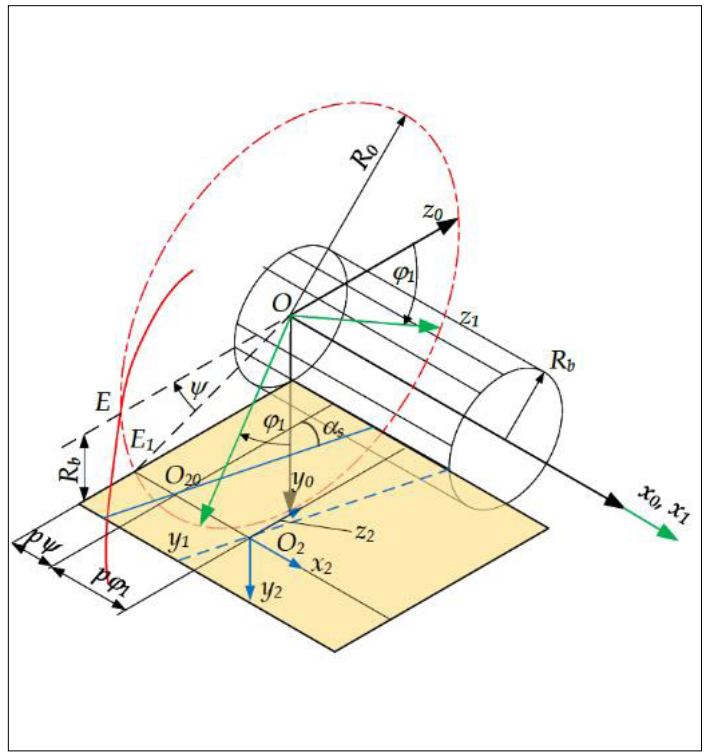

3. ábra. Az élek tájolása

A bal oldali fogárokfelületet (vagyis a menetszárny jobb oldali felületét) generáló, $O_{20}$ osztóhengeri ponttal rendelkező él $R_{b}$ távolságra van az $x_{0} z_{0}$ koordinátasíktól, így $\psi$ szöggel kell az $O x_{0}$ tengely körül elfordítani, hogy az osztóhengeri csavarvonalon haladva az E pontba érkezzen. Egyszerü geometriai megfontolások alapján felírható, hogy:

$$
\psi=\arcsin \frac{R_{b}}{R_{0}}=\frac{\pi}{2}-\alpha_{0 t}
$$

A generáló él mátrixos alakja a szerszámhoz kötött $\left(x_{2} y_{2} z_{2}\right)$ koordináta-rendszerben a következő:

$$
\underline{\boldsymbol{r}}_{2}=\left(\begin{array}{lll}
u \frac{p}{R_{b}} & 0 & u
\end{array}\right)^{T}
$$

A technológiai relatív kinematikát követő felületfelírás az él $O x_{0}$ tengely körüli p paraméterü csavarmozgását használja fel. A számítások mellőzésével a felület parametrikus egyenletei a következők:

$$
\left\{\begin{array}{c}
x_{0}\left(u, \varphi_{1}\right)=p\left(\varphi_{1}+\frac{u}{R_{b}}\right) \\
y_{0}\left(u, \varphi_{1}\right)=R_{b}\left(\cos \varphi_{1}+\left(\operatorname{tg} \alpha_{0 t}-\frac{u}{R_{b}}\right) \sin \varphi_{1}\right) \\
z_{0}\left(u, \varphi_{1}\right)=R_{b}\left(\sin \varphi_{1}-\left(\operatorname{tg} \alpha_{0 t}-\frac{u}{R_{b}}\right) \cos \varphi_{1}\right)
\end{array}\right.
$$

\subsection{Az elméleti felületek összehasonlítása}

Az elméletileg tökéletes evolvens csavarfelületek (4) és (8) függvényekkel megadott parametrikus egyenletei ugyanazokat a felületpontokat 
adják. Ezt a $(\varphi, \theta) \leftrightarrow\left(\varphi_{1}, u\right)$ paraméterek közötti bijektív kapcsolattal bizonyítjuk.

Az $x$-koordináták kiegyenlítéséből kapjuk, hogy

$$
\varphi=\varphi_{1}+\frac{u}{R_{b}}
$$

Másrészt, ha a polársugarakat egyenlítjük ki, kapjuk, hogy

$$
\theta-i n v \alpha_{0 t}+\varphi= \pm\left(\operatorname{tg} \alpha_{0 t}-\frac{u}{R_{b}}\right)
$$

A mínusz előjeles jobb oldali tagot tekintvén, és a (9) összefüggést behelyettesítvén a bal oldalba, a (10) egyenlet a következő alakot ölti:

$$
\theta+\alpha_{0 t}+\varphi_{1}=0 \Leftrightarrow \theta=-\left(\alpha_{0 t}+\varphi_{1}\right)
$$

Utóbbi egyenlet érdekes algebrai megközelítése a matematikai és a technológiai generálás ekvivalenciájának. A (4) parametrikus felírásban a $\theta$ paraméternek az értelme az evolvensgörbe létrehozásában nyilvánul meg, ahogyan azt az (1) egyenletekből láthatjuk. Ezzel szemben a (8) egyenletekben a $\varphi_{1}$ paraméter a generálást jelentő csavarmozgás rotációs összetevőjének mértékét fejezi ki. Bár a két paraméternek a funkcionális értelme különböző, a megfelelés geometria-kinematikai szempontból azért fogadható el, mert a matematikai generálás során adott elfordulási helyzetbe egyetlen homlokszelvényben illeszkednek a generált pontok, míg a kés esetében az alaphengert érintő egyenes szakasz mentén. Így, a (9) feltétel betartása mellett, ami azt jelenti, hogy kikötjük a két pont ugyanazon homlokmetszetben való illeszkedését, csak abban az esetben esnek egybe, ha a $\theta$ és a $\varphi_{1}$ között a (11) kapcsolat fennáll.

A számítógéppel végzett szimuláció során a kiszámított pontkoordináták közötti eltérés nagyságrendje $10^{-15}$.

\section{A gyártási hibák szimulációja}

A gyártási hibák a szerszám tájolásából, a szerszámgép geometriai hibájából és a szerszám profilhibájából erednek. Ezek hatását a továbbiakban egymástól függetlenül vizsgáljuk, mivel ezek független sztochasztikus változók.

\subsection{A kés központhibája}

A kés központhibáját az élsík tengelytől való távolságának az alapkörsugártól való eltérésében definiáljuk. Ennek céljából bevezetjük az $f$ súlyzót, az él $y$-koordinátája pedig a (7) mátrixban $R_{b}$ ről $f R_{b}$-re módosul. Ha $f>0$, akkor a kés süllyesztett, ha pedig $f<0$, akkor a kés emelt.
A parametrikus koordinátákat a csavarmozgás mátrixával és az él módosított oszlopával a következőképpen írjuk fel:

$$
\begin{aligned}
& \underline{\boldsymbol{r}}_{0}=\boldsymbol{M}_{02} \underline{\boldsymbol{r}}_{2} \\
& \boldsymbol{M}_{02}=\left(\begin{array}{cccc}
1 & 0 & 0 & p \varphi \\
0 & \cos \varphi & -\sin \varphi & a_{24} \\
0 & \sin \varphi & \cos \varphi & a_{34} \\
0 & 0 & 0 & 1
\end{array}\right) \\
& a_{24}=R_{b} \cos \varphi+\sqrt{R_{0}^{2}-R_{b}^{2}} \sin \varphi \\
& a_{34}=R_{b} \sin \varphi-\sqrt{R_{0}^{2}-R_{b}^{2}} \cos \varphi \\
& \underline{\boldsymbol{r}}_{2}=\left(\begin{array}{llll}
u \frac{p}{R_{b}} & f R_{b} & u & 1
\end{array}\right)^{T}
\end{aligned}
$$

A (12)...(14) egyenletekkel felírt csavarfelület sajátos alakja $f=0$-ra a tökéletes evolvens csavarfelület. Az $f R_{b}=\Delta h$ beállítási hiba legnagyobb értékére, a valós csavarfelületek lehetséges alterének harárait a $-\frac{\Delta h}{R_{b}} \leq f \leq \frac{\Delta h}{R_{b}} \quad f$-intervallumra kapjuk.

\subsection{A párhuzamossági hiba}

A párhuzamossági hibát az esztergapad tengelyvonala és a hosszanti előtolás irány közötti eltérés mértékével definiáljuk, $L=1000$ mm elmozdulási hosszon. Jelen közleményben a párhuzamossági hibát a vízszintes síkban értelmezettnek sajátosan, csak a forgástengelyen áthaladó vízszintes síkban értelmezzük, így a kés pályája nem párhuzamos a csiga forgástengelyével, hanem ezzel egy $\beta$ szöget zár be, ahol $\operatorname{tg} \beta \approx \beta=\delta_{p} / 10^{3}$. Ha $\delta_{p}=100 \mu \mathrm{m}$ párhuzamossági eltérést engedünk meg, ami a gép felújítás előtti állapotának pontossági jellemzője, akkor $\beta \approx 1 \cdot 10^{-4} \mathrm{rad}$, azaz 20,62 szögmásodperc.

Ebben az esetben a transzformáció $\mathbf{M}_{02}$ mátrixának utolsó oszlopa a következő alakot ölti:

$$
\left(\begin{array}{c}
p \varphi \\
-R_{b} \cos \varphi+\left(\sqrt{R_{0}^{2}-R_{b}^{2}}+p \varphi \beta\right) \sin \varphi \\
-R_{b} \sin \varphi-\left(\sqrt{R_{0}^{2}-R_{b}^{2}}+p \varphi \beta\right) \cos \varphi \\
1
\end{array}\right)
$$

Akár az előbbiekben, $-10^{-4} \leq \beta \leq 10^{-4}$ értékekre kapjuk meg a csavarfelület alterét. Jelen esetben úgy tekintettük, hogy a csiga hosszának közepére van helyezve a hozzá csatolt koordináta-rendszer. Ha a beállítás a csiga kezdőoldali homlokfelületén történik, akkor a koordináta-rendszer origóját is oda kell illeszteni ahhoz hogy a valóságnak megfelelő térbeli értelmezési tartományt kapjuk. 


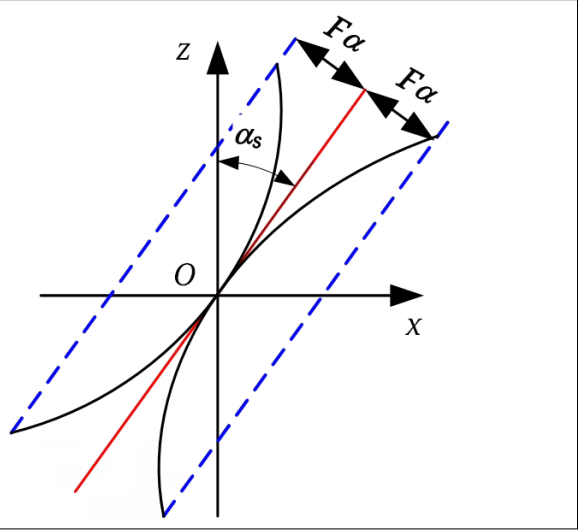

4. ábra. A profilhiba definíciója

\subsection{A profilhiba}

A profilhiba alatt a vágóél egyenes vonaltól való eltérését értjük (4. ábra). Ezt kétféleképpen fogalmazhatjuk meg: lehet az él tényleges alakjától való eltérésként felfogni, úgy, hogy az él egy konkáv vagy konvex görbe vonal, amely az elméleti egyenes által meghatározott egyik félsíkba illeszkedik, vagy pedig profilszöghibaként értelmezni. A profilhibát a fogaskerék-hibaszabványokban definiált $F_{\alpha}$ mennyiséggel azonosítjuk, és a numerikus kiértékelések során az N8-as pontossági osztályra alkalmazzuk [9]. Első esetben a hibás élalakot polinomfüggvényként definiáljuk. Az él hasznos hosszának kiterjedésén, azaz $2,25 m_{n} / \cos \alpha_{s}$ hosszon nem térhet el az $F_{\alpha}$ értéknél nagyobb értékkel, és érintenie kell az elméleti egyenest az origóban. Ez összességében négy feltételt jelent, aminek alapján pontosan négyismeretlenes lineáris egyenletrendszert lehet felállítani és négy együtthatót kiszámítani. Tehát a legegyszerübb polinom az origón áthaladó harmadfokú polinom, amelyet az

$$
\left\{\begin{array}{l}
x_{2}(u)=a_{1} u^{3}+b_{1} u^{2}+c_{1} u \\
z_{2}(u)=a_{2} u^{3}+b_{2} u^{2}+c_{2} u
\end{array}\right.
$$

alakban keresünk. (A szabad tag azért hiányzik, mert az egyenes élet úgy parametrizáltuk, hogy az osztóhengeren illeszkedő $\mathrm{O}_{2}$ origóban $u=0$.)

A 3. ábra alapján könnyen levezethető, hogy az u paraméter határai:

$$
\begin{aligned}
& u_{1}=-\left(\sqrt{R_{a}^{2}-R_{b}^{2}}-\sqrt{R_{0}^{2}-R_{b}^{2}}\right) ; \\
& u_{2}=\sqrt{R_{0}^{2}-R_{b}^{2}}-\sqrt{R_{f}^{2}-R_{b}^{2}} \\
& u_{1} \leq u \leq u_{2}
\end{aligned}
$$

A profilhibát az elméleti él teljes hosszára értelmezzük, az élre merőleges irányban, egyoldalú kiterjedéssel. Innen a konvex élalak kezdeti és végpontjának koordinátái:

$$
\begin{aligned}
& \left\{\begin{array}{l}
x_{21}=x_{2}\left(u_{1}\right)=u_{1} \operatorname{tg} \alpha_{s}-F_{\alpha} \cos \alpha_{s} \\
z_{21}=z_{2}\left(u_{1}\right)=u_{1}+F_{\alpha} \sin \alpha_{s}
\end{array}\right. \\
& \left\{\begin{array}{l}
x_{22}=x_{2}\left(u_{2}\right)=u_{2}-F_{\alpha} \cos \alpha_{s} \\
z_{21}=z_{2}\left(u_{1}\right)=u_{2}+F_{\alpha} \sin \alpha_{s}
\end{array}\right.
\end{aligned}
$$

A konkáv (jobb oldalra görbülő) élalak kezdeti és végpontjának koordinátái pedig:

$$
\begin{aligned}
& \left\{\begin{array}{l}
x_{21}=x_{2}\left(u_{1}\right)=u_{1} \operatorname{tg} \alpha_{s}+F_{\alpha} \cos \alpha_{s} \\
z_{21}=z_{2}\left(u_{1}\right)=u_{1}-F_{\alpha} \sin \alpha_{s}
\end{array}\right. \\
& \left\{\begin{array}{l}
x_{22}=x_{2}\left(u_{2}\right)=u_{2}+F_{\alpha} \cos \alpha_{s} \\
z_{21}=z_{2}\left(u_{1}\right)=u_{2}-F_{\alpha} \sin \alpha_{s}
\end{array}\right.
\end{aligned}
$$

Az érintési feltétel az origóban a következő alakra hozható:

$$
\operatorname{tg} \alpha_{s}=\left.\frac{\dot{z}}{\dot{x}}\right|_{u=0}=\frac{c_{2}}{c_{1}}
$$

A (20) feltételből azonnal kapjuk, hogy

$$
c_{1}=\cos \alpha_{s} ; c_{2}=\sin \alpha_{s} \text {, }
$$

ezzel pedig a (16), (18) és (19) kifejezések segítségével felépíthetjük az $a_{1}, a_{2}, b_{1}, b_{2}$-ben lineáris egyenletrendszert, amiből kifejezzük a parametrikus harmadfokú koordinátafüggvények együtthatóit.

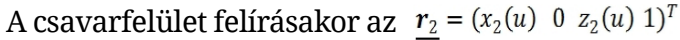
homogén koordinátaoszlopot alkalmazzuk.

\section{Számszerű kiértékelés}

A modell számszerü kiértékelését a következő lépésekben végezzük el:

- a kiválasztott hibaértékkel felírjuk a hibával terhelt csavarfelület egyenleteit, majd kiszámítjuk pontjainak koordinátáit, egy tetszőleges $\left(u_{1}, u_{2}\right) \times\left(\varphi_{1}, \varphi_{2}\right)$ paramétertartományon.

- kiszámítjuk a vezércsavarvonal $x_{0} z_{0}$ síkba illeszkedő pontjának $x_{0}^{*}$ koordinátáját;

-végrehajtjuk az $x^{\prime}=x_{0}-x_{0}^{*}$ tengelymenti elcsúsztatást;

- kiszámítjuk az adott pontból az ideális csavarfelületre húzott normális szakasz előjeles hosszát, ami maga a hiba.

A vizsgálatot $m_{n}=5 \mathrm{~mm}$ modulú, $\mathrm{i}=1$ bekezdésű, $\lambda_{0}=4^{\circ}$-os vezércsavarvonal-dőlésszögű evolvens csiga esetére végeztük el.

Elsősorban a magasságbeállítást vizsgáltuk $f=0,1$ és $f=0,2$ értékekre. A hiba eloszlását az 5. ábrán szemléltetjük.

Az ábra vizsgálata alapján kijelenthető, hogy a hibafaktor kétszeres növelésére a hiba maximális értéke több mint kétszeresére növekszik, tehát a 


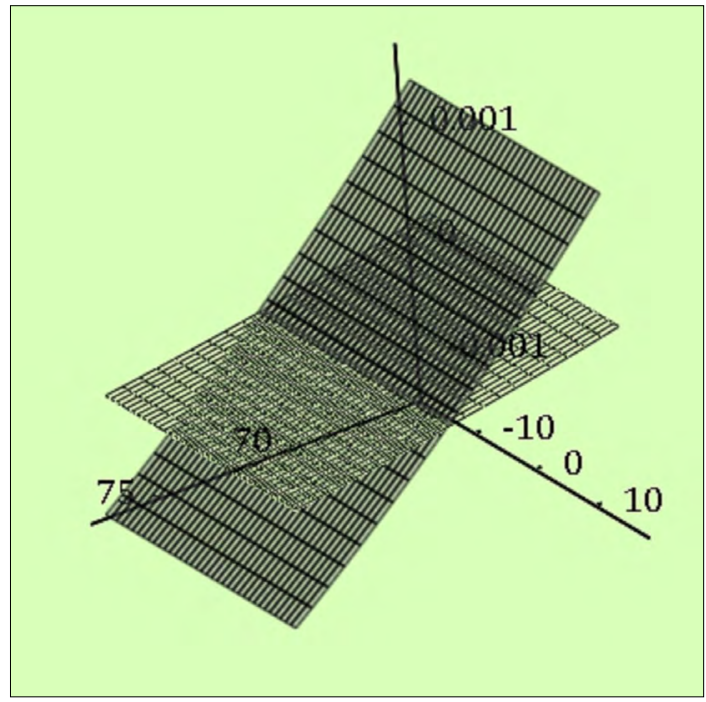

5. ábra. A késmagassághiba eloszlása

függőség nem lineáris. Ugyanakkor a hiba maximális értéke, $f=0,2$-re, ami $\Delta h=0,2 R_{b}=2,698 \mathrm{~mm}$ késmagassághibát jelent, $\Delta_{n h}=1,631 \mu \mathrm{m}$. Megfigyelhető a felületek alakjából, hogy a hiba pozitív a fej-, és negatív a lábhengeren. A pozitív hiba jelentése az, hogy a valós csavarfelület az elméletit fémbe zárja, míg a negatív azt, hogy az elméleti felületet elmetszi, azaz forgácsba söpri.

Kijelenthető, hogy a csigaesztergáláskor szokásos szerszámbeállítási hiba maximum értéke 0,1 mm, ami a profilhibát szubmikronikus tartományba szorítja vissza.

A profilhiba vizsgálatakor feltételeztük, hogy $F_{\alpha}=27 \mu \mathrm{m}$, N8-as pontossági osztályra. A hiba eloszlását a 6. ábrán szemléltettük.

A konkáv élhiba az alsó hibafelületet, a konvex pedig a felső hibafelületet generálja. Észre kell venni, hogy az osztóhengeren a hiba értéke nulla. Ez a geometriai modell és a számítások helyességét igazolja. A hibával terhelt (görbült) él osztóhengeren dolgozó pontjában ez az elméleti élet érinti.

Ellentétben a kés pozícióhibája okozta hibaeloszlással, itt az osztóhengertől távolodva a hiba nem változtat előjelt, hanem abszolút értékben közelítőleg parabolikus növekedést mutat.

A konkáv élhiba hatására az elméleti csavarfelületet a valós csavarfelület fémbe zárja, míg a konvex élhiba esetében ezt elmetszi.

Észre lehet venni, hogy ebben az esetben a hiba maximális értéke $\Delta_{n p} \approx 13 \mu \mathrm{m}$, vagyis a feltételezett profilhiba fele.

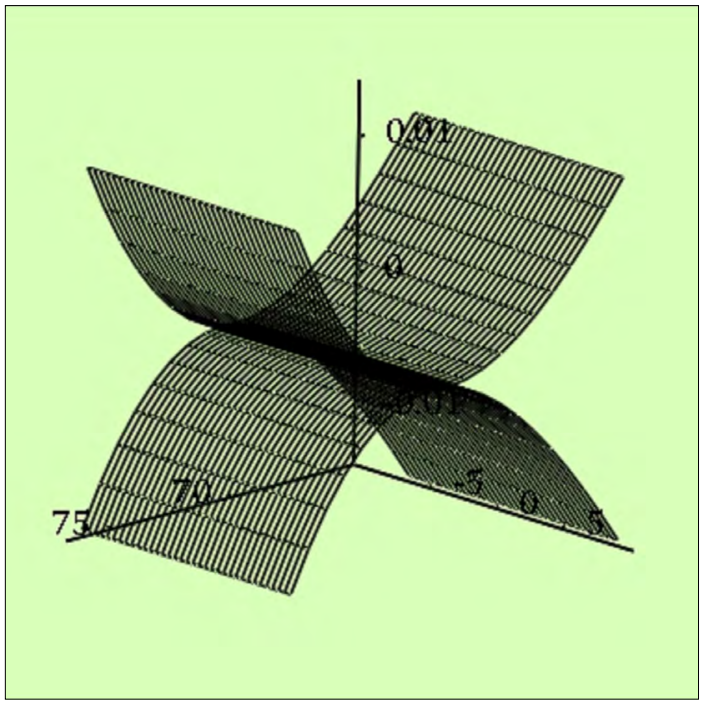

6. ábra. Az élprofilhiba okozta hibaeloszlások

A parabolikus modellt alkalmazhatjuk, minden számítás nélkül, arra az esetre, amikor az élnek nem profil-, hanem szöghibája van. Ez esetben a profiltürésmező közepén helyezkedik el az elméleti él, és legnagyobb szöghiba akkor áll fent, amikor a valós él átlósan szeli át a tűrésmezőt. Ebben az esetben az előbbi modellt az $F_{a} / 2$ értékre alkalmazzuk, és ennek következtében a várható profilhiba $\Delta_{n p} \approx 0,25 F_{\alpha}=7 \mu \mathrm{m}$ nagyságú lesz.

$\mathrm{Az}$ összegzett hiba számítását úgy végezzük el, hogy a két fő összetevőt egymástól független, normál eloszlású valószínűségi változónak vesszük. Eltekintünk a hiba irányától, azaz az előjelétől, így ennek csupán abszolút értéket tekintjük.

Jelölje a magassághiba következtében létrejött normálhibát kifejező sztochasztikus változót $\xi$, a profilhiba okozta normálhibát kifejezőt pedig $\eta$. A teljes szórásmező a nulla és a hiba maximális értéke között terjed, azaz

$$
\left\{\begin{array}{l}
0 \leq \xi \leq \Delta_{n h} \\
0 \leq \eta \leq \Delta_{n p}
\end{array}\right.
$$

Jó közelítéssel feltételezzük, hogy a kumulatív hiba várható értéke

$$
\bar{\zeta}=\bar{\xi}+\bar{\eta}=\frac{13}{2}+\frac{1,631}{2} \approx 7,35 \mu m
$$

A szórás értékét [10] jó becsléssel a szórásmező egyhatodának vesszük, a kompozícióváltozó, azaz a kumulatív hibaváltozó szórása pedig ezzel:

$$
\begin{aligned}
& \sigma_{\zeta}=\sqrt{\sigma_{\xi}^{2}+\sigma_{\eta}^{2}}=\frac{1}{6} \sqrt{\Delta_{n h}^{2}+\Delta_{n p}^{2}}= \\
& =\frac{1}{6} \sqrt{13^{2}+1,631^{2}} \approx 2,2 \mu \mathrm{m}
\end{aligned}
$$


Annak ellenére, hogy a két normáleloszlású sztochasztikus változó kompozíciója exponenciális eloszlású lesz [10], jelen esetben normáleloszlás-tulajdonsággal ruházzuk fel. A tapasztalat azt mutatja, hogy az eltérés jelentéktelen a gyakorlati alkalmazásokban. Hasonló modellt alkalmaznak a megmunkálási ráhagyások statisztikai számításakor is [11].

Ennek alapján a kumulatív hiba maximális értéke:

$$
\Delta_{\Sigma}=\bar{\zeta}+3 \sigma_{\zeta}=7.35+3 \cdot 2.2=13.95 \mu m
$$

\section{Következtetések}

Az előzőek során bemutatott matematikai modellek segítségével az evolvens csiga várható gyártási pontosságnak a becslését lehet elvégezni.

Ez azért fontos, hogy adott gyártási infrastruktúra pontosságának ismeretében bizonyosságot nyerjük arról, hogy adott csiga, az elvárt pontossággal, gyártható-e vagy sem.

A csiga hibájának forrását a kés magassághibájában, a kés profilhibájában és a szerszámgép párhuzamossághibájában kerestük. Utóbbiról eldöntöttük, hogy ez elhanyagolható, így az eredő hibát a kés magassághibájának és profilhibájának függvényében állítottuk fel.

A magassághibát és a profilhibát egymástól független valószínűségi változónak tekintettük.

A hiba kiértékelését a gyártási hibával terhelt felület és az elméletileg tökéletes felület közötti, az elméleti felületre normálirányú eltéréssel definiáltuk.

Értelmezésünk szerint a hiba pozitív, ha a valós felület az elméletit fémbe zárja, és negatív, ha ezt elmetszi, azaz forgácsba söpri.

A normálirányú eltérés számítására szintetikus geometriai modellt alkalmaztunk, melynek bemutatásától e közleményben eltekintettünk.

A numerikus vizsgálat azt mutatta ki, hogy a késmagassághiba a legkisebb befolyással van a kumulatív hibára, mivel ennek csupán 11,69\%-át teszi ki, még a modell vizsgálatakor alkalmazott túlzott mértékű jelenlétében is.

Végső soron jó közelítéssel lehet állítani, hogy az evolvens csavarfelület gyártási hibája a kés profilhibájának felével lesz egyenlő.
A menetvágó kinematikai lánc hibáját azért hanyagoltuk, mert a csiga felülete legtöbb 6-8 menetet tesz ki, amelynek megmunkálása alatt a vezércsavarhiba elhanyagolható. Ugyanakkor hozzá kell füzni, hogy a korszerü, numerikus vezérlésü szerszámgépek esetében a menetvágó kinematikai lánc hibái mikron nagyságrendűek.

\section{Szakirodalmi hivatkozások}

[1] Dudas I., Varga G., Banyai K.: Holonic manufacturing system for production of different sophisticated surfaces. Proceedings of the IASTED International Conference on Modelling, Simulation and Optimization (2004) 72-75.

[2] Balajti Zs.: Examination and adjustment of the bearing pattern in case of helicoid drive. 8th CIRP Conference on High Performance Cutting, Budapest, Hungary, June 25-27. 2018. Procedia CIRP, 77 (2018) 267-270.

[3] Balajti Zs., Dudás I.: The Monge Theorem and Its Application in Engineering Practice. The International Journal of Advanced Manufacturing Technology. Article 9763, Springer, London (2016). https://doi.org/10.1007/s00170-016-9763-1

[4] Dudas I.: The theory and practice of worm gear drives. Penton Press, London, 2000.

[5] I Tsay C. B., Tseng J. T.: Undercutting and contact characteristics of cylindrical gears with curvilinear shaped teeth generated by hobbing. Journal of Mechanical Design, 128/3. (2006) 634-643.

[6] Mohan L. V.: Geometrical aspects of double enveloping worm gear drive. Mechanism and Machine Theory, 44, (2009) 2053-2065.

[7] Radzevich S. P.: A way to improve the accuracy of hobbed involute gears. Journal of Mechanical design, 129/10. (2007), 1076-1085.

https://doi.org/10.1115/1.2761919

[8] Radzevich S. P.: Investigation of the tooth geometry of a hob for manufacturing of involute gears (in Tool-in-Use References System). Journal of Manufacturing Science and Engineering, 129/4. (2007), 750-759.

[9] KG Stock Gears: Gear Technical Data. 5.7 Precision of Spur and Helical gears. Letöltés: 2021. 04. 06. https://www.kggear.co.jp/en/wp-content/themes/ bizvektor-global-edition/pdf/5.7_Precision-ofSpur-and-Helical-gears_TechnicalData_KGSTOCKGEARS.pdf.

[10] Cseke V.: A valószínűségszámítás alapjai. Dacia Könyvkiadó, Kolozsvár, 1982.

[11] Drăghici G.: Tehnologia Construcțiilor de mașini. E.D.P., Bukarest, 1985. 